\title{
Coupling of Proton Transport across Planar Lipid Bilayer and Electron Transport Catalyzed by Membrane-bound Enzyme D-Fructose Dehydrogenase
}

\section{Kei HICHIRI, Osamu SHIRAI, * Yuki KITAZUMI, and Kenji KANO}

Division of Applied Life Sciences, Graduate School of Agriculture, Kyoto University, Sakyo, Kyoto 606-8502, Japan

*Corresponding author: shiraio@kais.kyoto-u.ac.jp

\begin{abstract}
Proton transport from an aqueous phase (W1) to another one (W2) across a planar bilayer lipid membrane (BLM) was driven by the electron transport system. The electron transport system was composed of the oxidation of D-fructose by an oxidized form of $D$-fructose dehydrogenase (FDH) at the W1|BLM interface, the oxidation of a reduced form of FDH by an oxidized form of 7,7,8,8-tetracyanoquinodimethane (TCNQ) at the W1|BLM interface and the oxidation of a reduced form of TCNQ by $\left[\mathrm{Fe}(\mathrm{CN})_{6}\right]^{3-}$ at the W2|BLM interface. Then the negative current due to the electron transfer from W1 to W2 was clearly observed around $0 \mathrm{~V}$. The zero-current potential varied to hold the electroneutrality in all phases by balancing the proton transport with the electron transport.
\end{abstract}

(C) The Electrochemical Society of Japan, All rights reserved.

Keywords : Bilayer Lipid Membrane, Electron Transport, Proton Transport, D-Fructose Dehydrogenase

\section{Introduction}

It has been generally recognized that transmembrane electron transport plays an important role in biological activities such as respiration, metabolism, etc. ${ }^{1-3}$ There are a lot of studies on the enzyme-catalyzed electron transport in biomembranes. ${ }^{4-6}$ The details of the electron transports in biomembranes, however, have not been well elucidated owing mainly to the complexity of the living organisms. On the other hand, some voltammetric studies have been carried out to examine the electron transport due to membrane-bound redox enzymes on solid electrodes modified with self-assembled monolayers (SAMs) or supported bilayer lipid membranes (sBLMs) ${ }^{7-9}$ However, the coupling mechanism of the electron transport with the cation transport in the biocell system represented as Scheme 1 cannot be understood by use of these electrodes. Frequently, the overall reaction (the electron transfer and the ion transfer) has been separately analyzed, and the charge balance is not strictly considered. Then, Koland, et al. indirectly observed the electron transport by a membrane-bound enzyme across a liposomal membrane containing adequate redox compounds. ${ }^{10}$ Although Sun and Mauzerall have reported a transmembrane proton pump driven by light by use of the lipid bilayer containing magnesium octaethylporphyrin and hydrophobic weak acids, ${ }^{11,12}$ the proton transport was qualitatively proved by the dependence of $\mathrm{pH}$. The author's group also identified the electron transport across the planar BLM in the presence of D-fructose dehydrogenase $(\mathrm{FDH})$ and 7,7,8,8-tetracyanoquinodimethane (TCNQ) within the BLM by electrochemical analysis. ${ }^{13}$

FDH from Gluconobacter frateurii is a heterotrimeric membranebound enzyme complex with a molecular mass of ca. $140 \mathrm{kDa}$ containing FAD and three hemes $c$ as the prosthetic groups. ${ }^{14,15}$ FDH serves as a catalyst of 2-electron oxidation of D-fructose to 5 -keto-D-fructose. ${ }^{16}$ This enzyme is known to react with some mediators, ${ }^{17,18}$ and we also reported that the electron transport across the BLM from one aqueous (W1) to another aqueous phase (W2) occurred by the use of TCNQ in the BLM and $\left[\mathrm{Fe}(\mathrm{CN})_{6}\right]^{3-}$ in W2. ${ }^{13}$ Although not only the electron transport across the BLM but also the transport of the coexisting cations across the BLM was

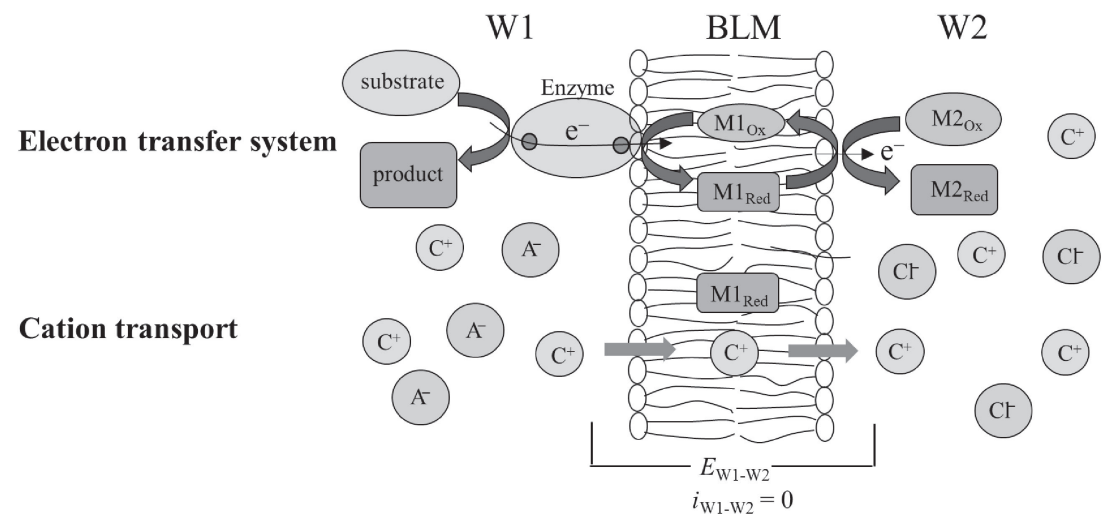

Scheme 1. Schematic model of the cation transport from W1 to W2 coupling with the electron transfer system composed of the oxidation of the substrate in W1, the redox of the membrane-bound enzyme and the redox of mediators in the BLM and W2 at the W1|BLM and BLM|W2 interfaces. 
simultaneously caused, details of the cation transport across the BLM and the coupling mechanism of the electron transport with the cation transport have not been elucidated yet.

In the present study, the FDH-catalyzed electron transport system across a planar BLM containing TCNQ as a mediator in the BLM was constructed, and the influence of both $\mathrm{pH}$ and the concentration of $\mathrm{KCl}$ on the electron transport across the BLM was evaluated. In addition, the coupling mechanism between the electron transport across the BLM and the ion transport across the BLM was elucidated based on the fact that the zero-current membrane potential varies to balance the coulomb number of the electron transport with that of the ion transport.

\section{Experimental}

\subsection{Chemicals}

Lecithin (PC, Wako Pure Chemical Ind., Ltd.) and cholesterol (Ch, Kanto Chemical Co. Inc.) were used to form planar BLMs. The BLM-forming solution was prepared by dissolving a mixture of about $10 \mathrm{mg}$ of $\mathrm{PC}$ and about $5 \mathrm{mg}$ of $\mathrm{Ch}$ into $1 \mathrm{~mL}$ of $n$-decane. TCNQ was used as a mediator in the BLM phase, and was obtained from Aldrich Chemical Co., Inc. (USA). In order to prepare a TCNQ-containing BLM, another BLM-forming solution was made by dissolving $10 \mathrm{mg}$ of $\mathrm{PC}$ and $5 \mathrm{mg}$ of $\mathrm{Ch}$ in $1 \mathrm{~mL}$ of an 1:9 mixture of 1,2-dichloroethane (DCE) containing TCNQ and $n$-decane. The concentration of TCNQ in the DCE solution was adjusted to $10 \mathrm{mM}$. Since TCNQ is insoluble in aqueous solution, TCNQ is expected to exist in the BLM or the stagnant organic solvents after the formation of the BLM. In this case, we identified by an UV-Vis spectrophotometer (Shimadzu Co., UV-2550) that a small part of TCNQ in the BLM-forming solution was reduced to one-electron reduced form $\left(\mathrm{TCNQ}^{\cdot-}\right)$ by lecithin. ${ }^{19-21}$

D-Fructose dehydrogenase (FDH) from Gluconobacter japonicus. was purchased from Toyobo Enzymes Co. and used without further purification. The concentration of FDH was confirmed from the absorbance determined at $550 \mathrm{~nm} .{ }^{14}$ All other reagents were of reagent grade.

\subsection{Voltammetric measurements}

An electrochemical cell used for voltammetric measurements with the BLM system was the same as that used in previous works. ${ }^{22}$ The BLM was formed as a black lipid membrane by brushing the BLM-forming solution on a $0.8-\mathrm{mm}$ diameter aperture created on a tetrafluoroethylene resin sheet of the electrochemical cell. The formation of the BLM was confirmed by microscopic observation and capacitance measurements. . $2,23^{2}$

The typical cell composition in the present study is shown by Eq. (1).

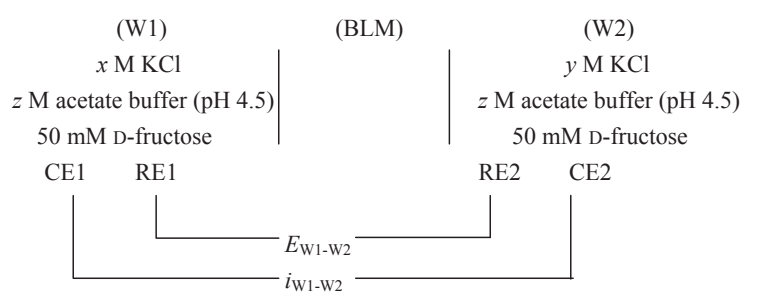

There are two aqueous compartments (W1 and W2) separated by the tetrafluoroethylene resin sheet of a thickness of $0.2 \mathrm{~mm}$, and they were filled with $15 \mathrm{~mL}$ of aqueous solution. The cell was then placed in a Faraday cage in order to decrease the background noise during electrochemical measurements. Cyclic voltammograms were recorded by the use of a four-electrode potentiostat (Hokuto Denko Co., HA1010mM1A), a function generator (Hokuto Denko Co., HB-105) and an A/D converter (Graphtec Co., GL900). The potential difference $\left(E_{\mathrm{W} 1-\mathrm{W} 2}\right)$ was applied between two $\mathrm{Ag} \mid \mathrm{AgCl}$ electrodes (RE1 and RE2) and the current $\left(i_{\mathrm{W} 1-\mathrm{W}_{2}}\right)$ between two $\mathrm{Pt}$ wire electrodes (CE1 and CE2) was recorded. All voltammograms were measured at a scan rate of $10 \mathrm{mV} \mathrm{s}^{-1}$ and at $25 \pm 1^{\circ} \mathrm{C}$, unless otherwise mentioned.

\section{Results and Discussions}

\subsection{Ion transport across the planar BLM in the presence of TCNQ $^{--}$and the absence of FDH in the BLM}

Curve 1 in Fig. 1 shows a cyclic voltammogram across the BLM in the absence of TCNQ between W1 and W2 containing $0.05 \mathrm{M}$ D-fructose and $0.1 \mathrm{M} \mathrm{KCl}$ in $0.02 \mathrm{M}$ acetate buffer ( $\mathrm{pH} 4.5$ ). Curve 2 is a cyclic voltammogram observed by adding TCNQ to the BLM. Furthermore, curve 3 was obtained on the addition of $10^{-4} \mathrm{M}$ $\mathrm{K}_{3}\left[\mathrm{Fe}(\mathrm{CN})_{6}\right]$ into W2. Although the BLM becomes usually unstable on the application of $E_{\mathrm{W} 1-\mathrm{W} 2}$ more than $0.1 \mathrm{~V}$, we barely obtained cyclic voltammograms in the potential region between -0.1 and $0.2 \mathrm{~V}$ by optimizing the pore size in the tetrafluoroethylene sheet. Thus, Faradaic current due to the transfer of any charging particle (ion or electron) wasn't observed, indicating that the BLM serves as a barrier to the permeation of hydrophilic ions such as $\mathrm{K}^{+}, \mathrm{Cl}^{-}$, etc. $^{22,23}$ When the BLM was formed with the BLM-forming solution containing $1 \mathrm{mM}$ TCNQ under the same conditions, the ion transport current symmetrical about the origin $(0 \mathrm{~V}, 0 \mathrm{~A})$ flowed across the BLM between $\mathrm{W} 1$ and $\mathrm{W} 2$, as indicated by curve 2 . Taking into account the reduction of TCNQ by lecithin and the acid dissociation of a proton-adduct of TCNQ $\left(\mathrm{TCNQH},[\mathrm{TCNQH}]=\left[\mathrm{TCNQ}^{-}\right]+\right.$ $\left[\mathrm{H}^{+}\right] ; \mathrm{p} K_{\mathrm{a}}=2.0$ (in aqueous solution)), ${ }^{24}$ it is thought that a part of TCNQ exists as TCNQ $^{-}$in the BLM. Since TCNQ ${ }^{-}$serves as a hydrophobic anion and is distributed to the BLM with coexistingcations, ${ }^{22,24,25} \mathrm{~K}^{+}$and $\mathrm{H}^{+}$seem to be candidates as counter cations distributed to the BLM with $\mathrm{TCNQ}^{--}$. Therefore, the relation between the $E_{\mathrm{W} 1-\mathrm{W} 2}$ at which the current was $0 \mathrm{~A}\left(E_{\mathrm{W} 1-\mathrm{W} 2, j=0}\right)$ and the ratio of the concentration of the cation $\left(\mathrm{K}^{+}\right.$or $\left.\mathrm{H}^{+}\right)$in $\mathrm{W} 1$ to that in W2 was investigated. Under the initial condition, W1 and W2 contained $0.05 \mathrm{M}$ D-fructose and $0.001 \mathrm{M} \mathrm{KCl}$ in $0.001 \mathrm{M}$ lithium acetate buffer $(\mathrm{pH} 4.5)$. When the concentration of $\mathrm{K}^{+}$in $\mathrm{W} 1$ increased up to 1,10 or 100 times larger than that in W2 by adding $3 \mathrm{M} \mathrm{KCl}$ to W1, the $E_{\mathrm{W} 1-\mathrm{W} 2, j=0}$ values didn't depend on the concentration ratio of $\mathrm{K}^{+}$at all, as shown in Fig. 2(a). Since the current due to the transfer of $\mathrm{K}^{+}$was observed in the absence of the buffer and the presence of TCNQ ${ }^{-}$, the author's group regarded $\mathrm{K}^{+}$as the transporting ion in a previous work. ${ }^{13}$ However, the data obtained in the present work indicate that $\mathrm{K}^{+}$doesn't mainly work as a counter ion of TCNQ ${ }^{-}$.

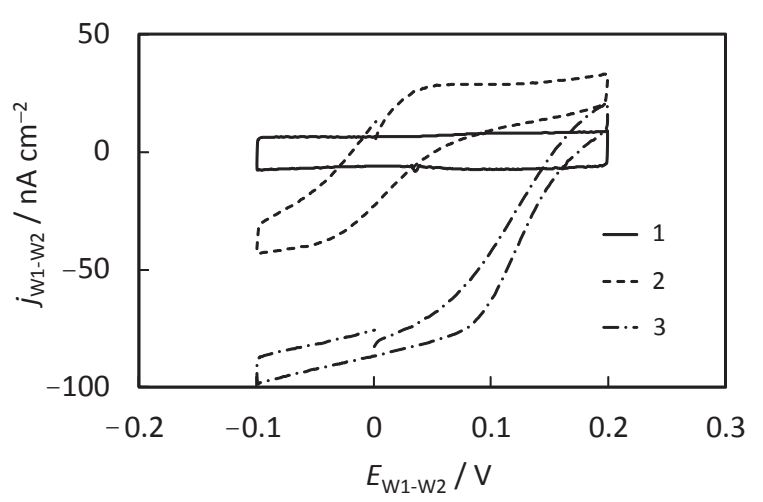

Figure 1. Cyclic voltammograms for charge transport across the BLMs. Curve 1: W1 and W2 contained $0.1 \mathrm{M} \mathrm{KCl}, 0.05 \mathrm{M}$ Dfructose and $0.02 \mathrm{M}$ potassium acetate buffer ( $\mathrm{pH}$ 5.0). Curve 2: as curve 1, but in the presence of TCNQ in the BLM. Curve 3: as curve 2, but in the presence of $10^{-4} \mathrm{M} \mathrm{K}_{3}\left[\mathrm{Fe}(\mathrm{CN})_{6}\right]$ in W2. Potential scanning rate: $10 \mathrm{mV} \mathrm{s}^{-1}$. 

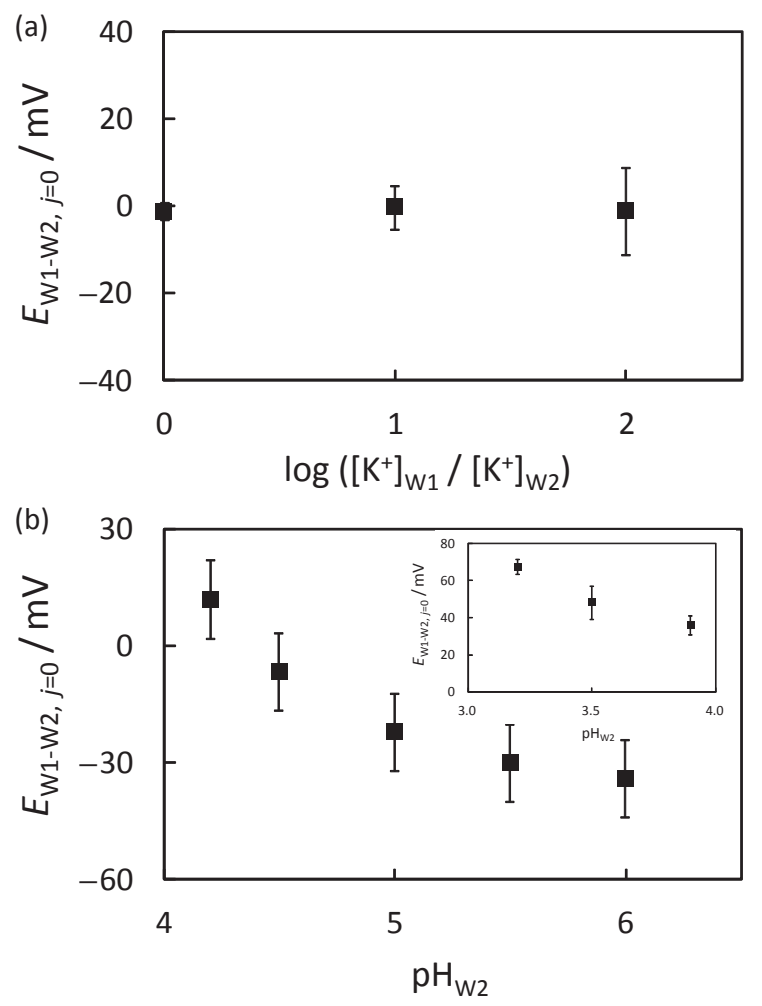

Figure 2. The relation between the ratio of the concentration of $\mathrm{K}^{+}(\mathrm{a})$ or $\mathrm{H}^{+}(\mathrm{b})$ in $\mathrm{W} 1$ to that in $\mathrm{W} 2$ and the zero-current membrane potential, $E_{\mathrm{W} 1-\mathrm{W} 2, j=0}$. (a) W1 contained $0.001 \mathrm{M} \mathrm{KCl}, 0.05 \mathrm{M}$ Dfructose and $0.001 \mathrm{M}$ lithium acetate buffer (pH 4.2). W2 contained $0.001-0.100 \mathrm{M} \mathrm{KCl}, 0.05 \mathrm{M}$ D-fructose and $0.001 \mathrm{M}$ lithium acetate buffer (pH 4.5). (b) $\mathrm{W} 1$ and $\mathrm{W} 2$ contained $0.001 \mathrm{M} \mathrm{KCl}, 0.05 \mathrm{M}$ D-fructose and $0.001 \mathrm{M}$ lithium acetate buffer. $\mathrm{pH}$ in $\mathrm{W} 1: 4.2, \mathrm{pH}$ in W2: 4.2, 4.5, 5.0, 5.5, 6.0. The inset shows the dependence of $E_{\mathrm{W} 1-\mathrm{W} 2, j=0}$ on the $\mathrm{pH}$ value in $\mathrm{W} 2$ when W1 contained $1 \mathrm{mM}$ potassium acetate buffer $(\mathrm{pH} 4.5), 0.01 \mathrm{M} \mathrm{KCl}$ and $0.05 \mathrm{M}$ Dfructose and W2 contained $1 \mathrm{mM}$ sodium citrate buffer $(\mathrm{pH} 3.2,3.5$ and 3.9), $20 \mathrm{nM} \mathrm{FDH}, 0.01 \mathrm{M} \mathrm{KCl}$ and $0.05 \mathrm{M}$ D-fructose.

Next, the influence of the concentration of $\mathrm{H}^{+}$was investigated in the following manner. The $\mathrm{pH}$ values of $\mathrm{W} 1$ and $\mathrm{W} 2$ were adjusted to 4.2 after the formation of the BLM. Thereafter the $\mathrm{pH}$ value of W2 was changed from 4.2 to $4.5,5.0,5.5$ and 6.0 by adding suitable amounts of $1 \mathrm{M} \mathrm{NaOH}$ to W2. Here, we confirmed by the addition of $\mathrm{NaCl}$ that $\mathrm{Na}^{+}$did not participate in the ion transport at all. The $E_{\mathrm{W} 1-\mathrm{W} 2, j=0}$ value was shifted in the negative direction with an increase of $\mathrm{pH}$ in W2, as shown in Fig. 2(b). This behavior indicates that $\mathrm{H}^{+}$is a main transporting cation. It seems reasonable to assume that the supply of $\mathrm{H}^{+}$at the W1|BLM interface is abundant by considering the buffer capacity at $\mathrm{pH} 4-6$ and $\mathrm{TCNQ}^{--}$can work as a carrier of $\mathrm{H}^{+}$within the BLM in the $\mathrm{pH}$ region. ${ }^{26}$ However, the slope of the variation decreased in the $\mathrm{pH}$ region above $\mathrm{pH} 5$ in spite of the strong buffer capacity. This seems to be attributable to an influence of the transport of $\mathrm{K}^{+}$, as reported in the previous work. ${ }^{13}$ Incidentally, liquid junction potentials in the asymmetric composition of $\mathrm{K}^{+}$and $\mathrm{H}^{+}$were generated between reference electrodes and aqueous phases (W1 and W2), but they were estimated less than $2 \mathrm{mV}$ and $0.2 \mathrm{mV}$, respectively, by using Henderson equation. ${ }^{27}$

\subsection{Electron transport across the planar BLM in the presence} of FDH in W1, TCNQ in BLM and $\left[\mathrm{Fe}(\mathrm{CN})_{6}\right]^{3-}$ in W2

In the presence of FDH in W1, FDH is easily adsorbed on the surface of the BLM. If a reduced form of FDH $\left(\mathrm{FDH}_{\mathrm{Red}}\right)$ is formed by the oxidation of $\mathrm{D}$-fructose in $\mathrm{W} 1$, it has been reported that TCNQ is easily reduced to TCNQ ${ }^{-}$by $\mathrm{FDH}_{\text {Red }}{ }^{13}$ In this case, FDH catalyzes 2-electron oxidation of D-fructose first, as written by Eq. (2). ${ }^{16}$

$$
\mathrm{FDH}_{\mathrm{Ox}}+\mathrm{D} \text {-fructose } \rightarrow \mathrm{FDH}_{\mathrm{Red}}+\text { 5-keto-D-fructose }
$$

Here, $\mathrm{FDH}_{\mathrm{Ox}}$ represents an oxidized form of FDH. Then $\mathrm{FDH}_{\text {Red }}$ donates the electron to TCNQ in the vicinity of the W1|BLM interface as Eq. (3).

$$
\mathrm{FDH}_{\text {Red }}+2 \mathrm{TCNQ} \rightarrow \mathrm{FDH}_{\mathrm{Ox}}+2 \mathrm{TCNQ}^{\cdot-}
$$

On the addition of D-fructose and FDH to W1, TCNQ to the BLM and $\left[\mathrm{Fe}(\mathrm{CN})_{6}\right]^{3-}$ to $\mathrm{W} 2$, the electron transfer system is constructed. In order to demonstrate the mechanism of the electron transfer system, the influence of above components is investigated as follows. In the absence of TCNQ in the BLM system, Faradaic current due to the transfer of any ions or an electron wasn't observed, as shown by curve 1 of Fig. 1 . When $20 \mathrm{nM}$ of FDH was added into the cell system containing TCNQ, a sigmoidal curve symmetrical about the origin $(0 \mathrm{~V}, 0 \mathrm{~A})$ was observed like curve 2 in Fig. 1. In the presence of TCNQ, most of TCNQ seems to be reduced to TCNQ ${ }^{--}$by $\mathrm{FDH}_{\mathrm{Red}}$, as written by Eq. (3). Therefore, $\mathrm{H}^{+}$ is distributed from the aqueous phases to the BLM with TCNQ ${ }^{-}$, and $\mathrm{H}^{+}$is transported across the BLM in a similar manner as described in the previous section. The inset of Fig. 2(b) indicates the relation between $E_{\mathrm{W} 1-\mathrm{W} 2, j=0}$ and the $\mathrm{pH}$ value in W2. After the BLM was formed between $\mathrm{W} 1$ and $\mathrm{W} 2$ containing $0.01 \mathrm{M} \mathrm{KCl}$ and $0.05 \mathrm{M}$ D-fructose, the $\mathrm{pH}$ values of $\mathrm{W} 1$ and $\mathrm{W} 2$ were adjusted to 3.2 by addition of an acetate buffer $(0.001 \mathrm{M})$ to $\mathrm{W} 1$ and of a citrate buffer $(0.001 \mathrm{M})$ to $\mathrm{W} 2$. Then, the $\mathrm{pH}$ value of W2 was changed from 3.2 to 3.5 and 4.0 by adding $1 \mathrm{M} \mathrm{NaOH}$ to W2. Because of the dependence of $E_{\mathrm{W} 1-\mathrm{W} 2, j=0}$ on $\mathrm{pH}$, it can be considered that $\mathrm{H}^{+}$is a predominant transporting ion and that $\mathrm{TCNQ}^{--}$serves as a carrier of $\mathrm{H}^{+}$in the BLM.

When W1 and $\mathrm{W} 2$ contained $50 \mathrm{mM}$ D-fructose and $0.1 \mathrm{M} \mathrm{KCl}$ in a $20 \mathrm{mM}$ acetate buffer ( $\mathrm{pH} 4.5)$ and the BLM contained TCNQ, the ion transport current symmetrical about the origin flowed across the BLM between W1 and W2 like curve 2 of Fig. 1. Although the waveform of the cyclic voltammogram remained unchanged on the addition of FDH $(20 \mathrm{nM})$ to $\mathrm{W} 1$, the magnitude of the current at the same $E_{\mathrm{W} 1-\mathrm{W} 2}$ increased. The increase in the current density seems to be caused by an increase in the amount of $\mathrm{TCNQ}^{--}$within the BLM due to the reduction of TCNQ by FDH bound on the BLM. The electron transport across the BLM from W1 to W2 occurred on the addition of $\left[\mathrm{Fe}(\mathrm{CN})_{6}\right]^{3-}\left(10^{-4} \mathrm{M}\right)$ into $\mathrm{W} 2$, as shown by curve 3 of Fig. 1. The negative current due to the electron transport across the BLM from $\mathrm{W} 1$ to $\mathrm{W} 2$ was observed in the potential range more negative than $0.15 \mathrm{~V}$. The electron transport is generated by coupling the oxidation of D-fructose by $\mathrm{FDH}_{\mathrm{Ox}}$ at the W1|BLM interface, the reduction of TCNQ by $\mathrm{FDH}_{\text {Red }}$ at the W1|BLM interface and the reduction of $\left[\mathrm{Fe}(\mathrm{CN})_{6}\right]^{3-}$ by $\mathrm{TCNQ}^{--}$at the $\mathrm{BLM} \mid \mathrm{W} 2$ interface, as illustrated in Scheme 2. The current in the potential region from $-0.1 \mathrm{~V}$ to $0.1 \mathrm{~V}$ didn't increase by adding $\mathrm{D}$-fructose in $\mathrm{W} 1$ even at more than $50 \mathrm{mM}$, nor depend on the potential scanning rate. Since the further addition of FDH or TCNQ to W1 enhanced the current due to the electron transport, the reduction of TCNQ by $\mathrm{FDH}_{\text {Red }}$ at the W1|BLM interface is presumed as the rate-determining step of the electron transport in this potential region.

\subsection{Proton transport across the BLM promoted by electron transport}

Figure 3 exhibits cyclic voltammograms (curves 1-5) for the charge transport across the BLM containing TCNQ between W1 containing FDH and D-fructose and W2 containing $0,10^{-6}, 10^{-5}$, $10^{-4}$ and $10^{-3} \mathrm{M}$ of $\mathrm{K}_{3}\left[\mathrm{Fe}(\mathrm{CN})_{6}\right]$. In the absence of $\mathrm{K}_{3}\left[\mathrm{Fe}(\mathrm{CN})_{6}\right]$ in $\mathrm{W} 2$, the electron transport didn't occur at all, as presented by curve 1 . In the presence of $10^{-6} \mathrm{M} \mathrm{K}_{3}\left[\mathrm{Fe}(\mathrm{CN})_{6}\right]$ in W2, not only the proton transport but also the electron transport appeared, as shown 


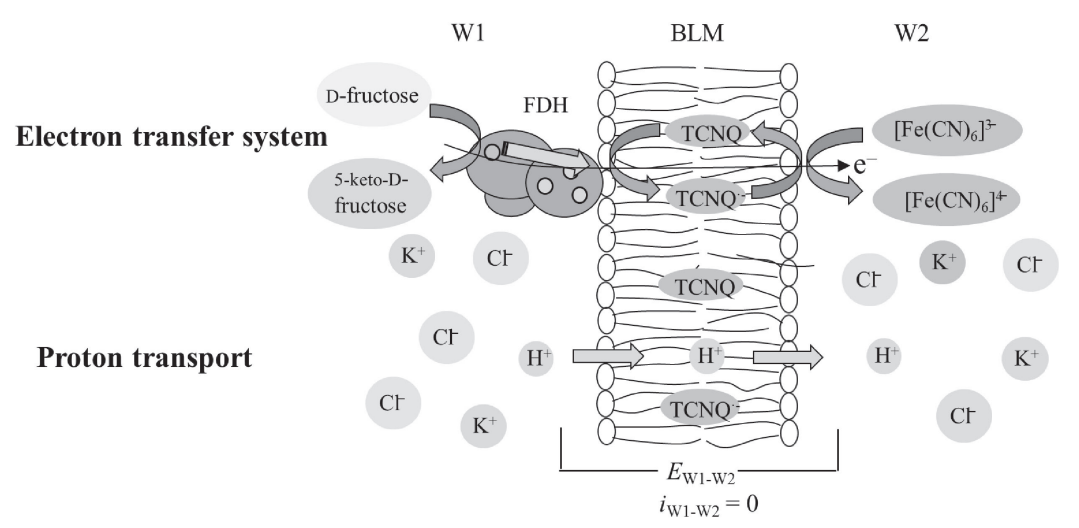

Scheme 2. Schematic model of the proton transport from W1 to W2 coupling with the electron transfer system.

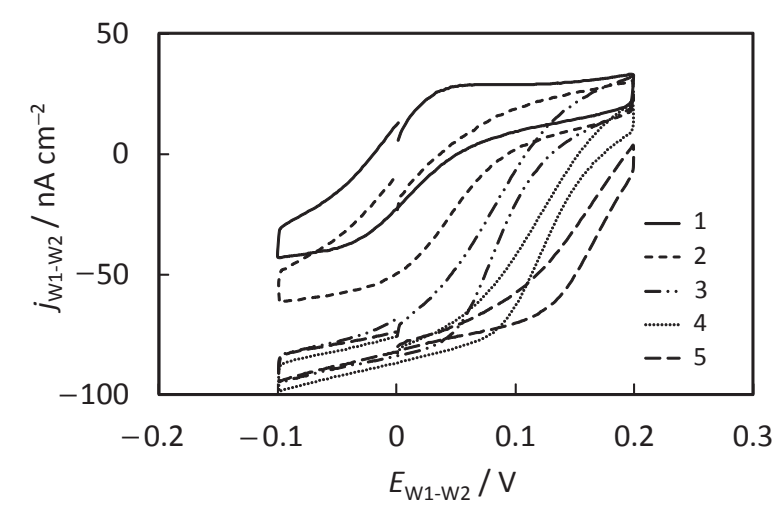

Figure 3. Cyclic voltammograms for the charge transport across the BLMs. Curve 1: W1 contained $0.1 \mathrm{M} \mathrm{KCl}, 0.05 \mathrm{M}$ D-fructose, $20 \mathrm{nM} \mathrm{FDH}$ and $0.02 \mathrm{M}$ potassium acetate buffer ( $\mathrm{pH} 4.5)$, BLM contained TCNQ and W2 contained $0.1 \mathrm{M} \mathrm{KCl}, 0.05 \mathrm{M}$ D-fructose and $0.02 \mathrm{M}$ potassium acetate buffer $(\mathrm{pH} 4.5)$. Curves 2-5: as curve 1 , but in the presence of $10^{-6}, 10^{-5}, 10^{-4}$ and $10^{-3} \mathrm{M} \mathrm{K}_{3}\left[\mathrm{Fe}(\mathrm{CN})_{6}\right]$ in $\mathrm{W} 2$. Potential scanning rate: $10 \mathrm{mV} \mathrm{s}^{-1}$.

by curve 2 . The negative current due to the electron transport from $\mathrm{W} 1$ to $\mathrm{W} 2$ began to flow below about $0.15 \mathrm{~V}$. When the concentration of $\mathrm{K}_{3}\left[\mathrm{Fe}(\mathrm{CN})_{6}\right]$ was higher than $10^{-5} \mathrm{M}$, the negative limiting current appeared and it was independent of the concentration of $\mathrm{K}_{3}\left[\mathrm{Fe}(\mathrm{CN})_{6}\right]$ in the potential range between $-0.1 \mathrm{~V}$ and $0.1 \mathrm{~V}$. The slope of the negative limiting current between $-0.1 \mathrm{~V}$ and $0.1 \mathrm{~V}$ was about $130 \mathrm{nA} \mathrm{V}^{-1} \mathrm{~cm}^{-2}$, and it is about half of the change in $j_{\mathrm{W} 1-\mathrm{W} 2}$ of curve 1 between $-0.1 \mathrm{~V}$ and $0.1 \mathrm{~V}$ (about $280 \mathrm{nA} \mathrm{V}^{-1} \mathrm{~cm}^{-2}$ ). When the electron transport across the BLM occurred, $\mathrm{TCNQ}^{--}$was served as not only an proton carrier but also an electron carrier. Since the ratio of $\mathrm{TCNQ}^{--}$to $\mathrm{TCNQ}$ within the BLM decreased as compared to the proton transport in the absence of $\mathrm{K}_{3}\left[\mathrm{Fe}(\mathrm{CN})_{6}\right]$ in $\mathrm{W} 2$, the current due to the transport of $\mathrm{H}^{+}$ observed in curves $3-5$ is assumed to become small. Thus, the slope of the negative limiting current is seemed to be caused by the proton transport. When $E_{\mathrm{W} 1-\mathrm{W} 2}$ was more positive than $0 \mathrm{~V}$, the proton transport across the BLM from $\mathrm{W} 1$ to $\mathrm{W} 2$ was observed. To the contrary, the proton transport across the BLM from W2 to W1 occurred in the negative region of $E_{\mathrm{W} 1-\mathrm{W} 2}$. Incidentally, the $E_{\mathrm{W} 1-\mathrm{W} 2, j=0}$ value shifted in the positive direction with increasing the concentration of $\mathrm{K}_{3}\left[\mathrm{Fe}(\mathrm{CN})_{6}\right]$ in $\mathrm{W} 2$.

\subsection{Influence of the ratio of $\left[\mathrm{Fe}(\mathrm{CN})_{6}\right]^{3-}$ to $\left[\mathrm{Fe}(\mathrm{CN})_{6}\right]^{4-}$ in $\mathrm{W} 2$ on} the proton transport coupling with the electron transport

In order to elucidate the dependence of the $E_{\mathrm{W} 1-\mathrm{W} 2, j=0}$ value on the ratio of $\left[\mathrm{Fe}(\mathrm{CN})_{6}\right]^{3-}$ to $\left[\mathrm{Fe}(\mathrm{CN})_{6}\right]^{4-}$ in $\mathrm{W} 2$, the ratio of

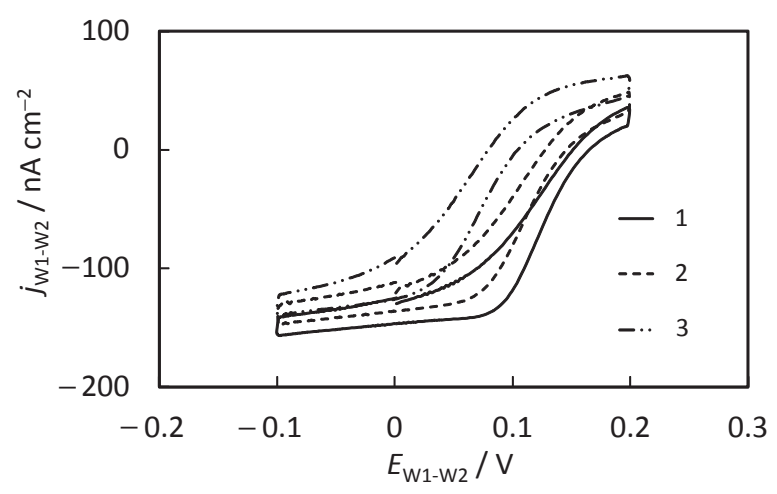

Figure 4. Cyclic voltammograms for the charge transport across the BLMs. Curve 1: W1 contained $0.1 \mathrm{M} \mathrm{KCl}, 0.05 \mathrm{M}$ D-fructose, $20 \mathrm{nM} \mathrm{FDH}$ and $0.02 \mathrm{M}$ potassium acetate buffer ( $\mathrm{pH} 4.5$ ), BLM contained TCNQ and $\mathrm{W} 2$ contained $0.1 \mathrm{M} \mathrm{KCl}, 0.05 \mathrm{M}$-fructose, $10^{-4} \mathrm{M} \mathrm{K}_{3}\left[\mathrm{Fe}(\mathrm{CN})_{6}\right], 10^{-5} \mathrm{M} \mathrm{K}_{4}\left[\mathrm{Fe}(\mathrm{CN})_{6}\right]$ and $0.02 \mathrm{M}$ potassium acetate buffer ( $\mathrm{pH} 4.5)$. Curves 2 and 3 : as curve 1, but in the presence of $10^{-4}$ and $10^{-3} \mathrm{M} \mathrm{K}_{4}\left[\mathrm{Fe}(\mathrm{CN})_{6}\right]$ in W2. Potential scanning rate: $10 \mathrm{mV} \mathrm{s}^{-1}$.

$\left[\mathrm{Fe}(\mathrm{CN})_{6}\right]^{3-}$ to $\left[\mathrm{Fe}(\mathrm{CN})_{6}\right]^{4-}$ was set to be 10,1 and 0.1 by addition of $0.1 \mathrm{M} \mathrm{K}_{4}\left[\mathrm{Fe}(\mathrm{CN})_{6}\right]$ to $\mathrm{W} 2$. The voltammograms are given as curves $1-3$ in Fig. 4 . At the ratio of $\left[\mathrm{Fe}(\mathrm{CN})_{6}\right]^{3-}$ to $\left[\mathrm{Fe}(\mathrm{CN})_{6}\right]^{4-}$ of 10,1 and 0.1 , onset potentials were $0.06,0.10$ and $0.13 \mathrm{~V}$, respectively. This indicates that the shift of the onset potential is mainly caused by the shift of $E_{\mathrm{W} 2 \mid \mathrm{BLM}}$ determined by the ratio of $\left[\mathrm{Fe}(\mathrm{CN})_{6}\right]^{3-}$ to $\left[\mathrm{Fe}(\mathrm{CN})_{6}\right]^{4-}$.

Figure 5 exhibits schematic voltammograms for the electron transport at the W1|BLM and the BLM|W2 interfaces. The redox reaction of the TCNQ ${ }^{-} \mid \mathrm{TCNQ}$ couple occurred at both W1|BLM and $\mathrm{BLM} \mid \mathrm{W} 2$ interfaces. In order to simplify the system, the ratio of $\left[\mathrm{TCNQ}^{-}\right]$to $[\mathrm{TCNQ}]$ within the BLM was assumed to be constant $(=1)$. If the diffusion coefficient of $\mathrm{TCNQ}^{-}$in the BLM is equivalent to that of TCNQ in the BLM, it is thought that this assumption is reasonable because of the appearance of the steadystate current. Therefore, the potential differences at the W1|BLM and the $\mathrm{BLM} \mid \mathrm{W} 2$ interfaces $\left(E_{\mathrm{W} 1 \mid \mathrm{BLM}}\right.$ and $\left.E_{\mathrm{BLM} \mid \mathrm{W} 2}\right)$ are expressed versus the formal redox potential of the TCNQ ${ }^{-} \mid \mathrm{TCNQ}$ couple $\left(0.127 \mathrm{~V}\right.$ vs. SCE) in this figure. ${ }^{28}$ The negative current due to the reduction of TCNQ flows at the W1|BLM interface, as represented by curve 1 . Since the current flows by the redox reaction of the $\left[\mathrm{Fe}(\mathrm{CN})_{6}\right]^{3-} \mid\left[\mathrm{Fe}(\mathrm{CN})_{6}\right]^{4-}$ couple $(0.370 \mathrm{~V}$ vs. SCE $)$ at the BLM $\mid \mathrm{W} 2$ interface, ${ }^{29}$ schematic voltammograms (at the ratio of $\left[\mathrm{Fe}(\mathrm{CN})_{6}\right]^{3-}$ to $\left[\mathrm{Fe}(\mathrm{CN})_{6}\right]^{4-}$ of 10,1 and 0.1$)$ are drawn as curves $2-4$. Here, the schematic curves $2-4$ are depicted with inversion of the current by considering the electric properties of the cell. It is thought that the 

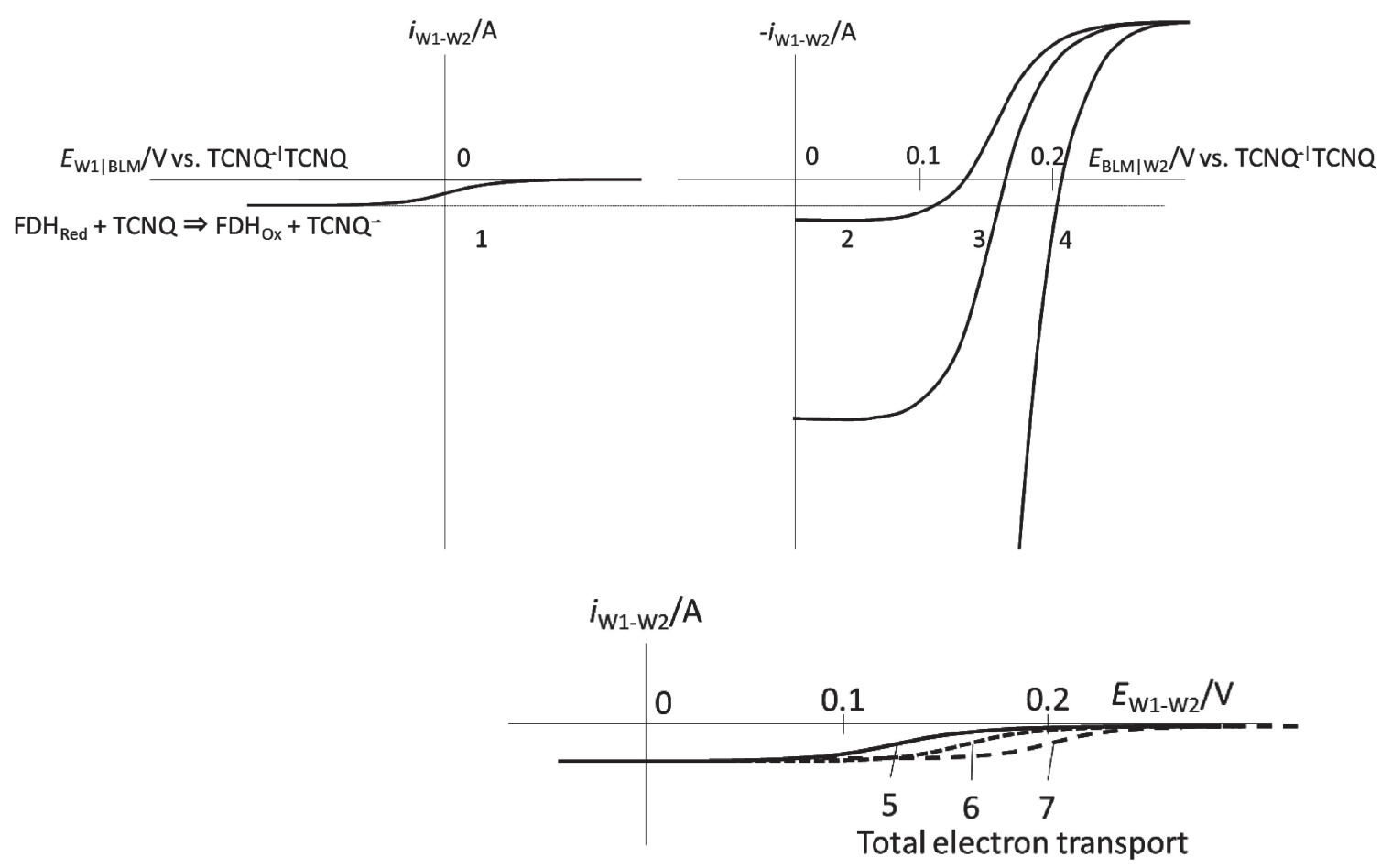

Figure 5. Schematic voltammograms for the electron transport across the BLM containing TCNQ between W1 containing FDH and D-fructose and $\mathrm{W} 2$ containing $\mathrm{K}_{3}\left[\mathrm{Fe}(\mathrm{CN})_{6}\right]$. Curve 1: schematic voltammogram at the W1|BLM interface. Curves 2-4: schematic voltammograms at the BLM $\mid \mathrm{W} 2$ interface. The ratio of $\mathrm{K}_{3}\left[\mathrm{Fe}(\mathrm{CN})_{6}\right]$ to $\mathrm{K}_{4}\left[\mathrm{Fe}(\mathrm{CN})_{6}\right]$ : 0.1 (curve 2), 1 (curve 3) and 10 (curve 4). Curves 5-7: schematic voltammogram across the BLM. The ratio of $\mathrm{K}_{3}\left[\mathrm{Fe}(\mathrm{CN})_{6}\right]$ to $\mathrm{K}_{4}\left[\mathrm{Fe}(\mathrm{CN})_{6}\right]$ : 0.1 (curve 5), 1 (curve 6) and 10 (curve 7).

half-wave potential of the negative current wave corresponds to the sum of the formal redox potential of the TCNQ ${ }^{--} \mid \mathrm{TCNQ}$ couple and that of the $\left[\mathrm{Fe}(\mathrm{CN})_{6}\right]^{3-} \mid\left[\mathrm{Fe}(\mathrm{CN})_{6}\right]^{4-}$ couple. However, the reduction of $\left[\mathrm{Fe}(\mathrm{CN})_{6}\right]^{3-}$ at the BLM|W2 interface is limited by the reduction of TCNQ at the W1|BLM interface by considering the electroneutrality within the BLM. As for the electron transport at the W1|BLM interface, the negative current due to the reduction of TCNQ flowed, as represented by the broken line. Accordingly, the negative current for the electron transfer from the BLM to W2 is limited by the current due to the reduction of TCNQ, as shown by line 5. On the other hand, the electron transfer from W2 to the BLM hardly occurs, because the reduction of 5-keto-D-fructose to Dfructose by $\mathrm{FDH}_{\text {Red }}$ doesn't take place at all. ${ }^{16}$ The positive current for the electron transport from W2 to the BLM is also restricted. Taking into account the relation among curves $1-4$, curves 5-7 are obtained as the schematic voltammograms for the electron transport across the BLM between $\mathrm{W} 1$ and W2.

Based on the Goldman-Hodgkin-Katz equation, ${ }^{30}$ the flux of an ion $\mathrm{i}\left(J_{\mathrm{i}},\right)$ is given as Eq. (4).

$$
J_{\mathrm{i}}=-\frac{D_{\mathrm{i}} z_{\mathrm{i}} F}{R T d} \Delta E \beta_{\mathrm{i}}\left\{\frac{c_{\mathrm{i}}^{\mathrm{W} 2} \exp \left(\frac{z_{\mathrm{i}} F}{R T} \Delta E\right)-c_{\mathrm{i}}^{\mathrm{W} 1}}{\exp \left(\frac{z_{\mathrm{i}} F}{R T} \Delta E\right)-1}\right\}
$$

Here, $D_{\mathrm{i}}$ is the diffusion coefficient of $\mathrm{i}$ within the BLM, $z_{\mathrm{i}}$ the charge number of i, $F$ the Faraday constant, $R$ the gas constant, $T$ temperature, $d$ the thickness of the BLM, $\Delta E$ the potential difference between $\mathrm{W} 1$ and $\mathrm{W} 2, c_{\mathrm{i}}^{\mathrm{W} 1}$ the concentration of $\mathrm{i}$ in $\mathrm{W} 1$ and $c_{\mathrm{i}}{ }^{\mathrm{W} 2}$ the concentration of $\mathrm{i}$ in $\mathrm{W} 2$. The transport ions are $\mathrm{H}^{+}$and $\mathrm{TCNQ}^{-\cdot}$ in the present case. Since the concentration of $\mathrm{TCNQ}^{-\bullet}$ in $\mathrm{W} 1$ and $\mathrm{W} 2$ is negligibly small, the total ion transport current, $i_{\text {total }}$, is equal to the current for the proton transport.

The distribution coefficient of $\mathrm{MX}(\beta)$ is expressed as Eq. (5) based on the distribution of ions at aqueous|organic interface. ${ }^{31}$

$$
\ln \beta=-\frac{\Delta G_{\mathrm{tr}, \mathrm{M}^{+}}^{\circ}+\Delta G_{\mathrm{tr}, \mathrm{X}^{-}}^{\circ}}{2 R T}
$$

where $\Delta G_{\mathrm{tr}, \mathrm{i}}^{\circ}$ is the standard molar Gibbs energy of the transfer of $\mathrm{i}\left(\mathrm{M}^{+}\right.$and $\left.\mathrm{X}^{-}\right)$from the aqueous phase to the organic phase. In addition, the potential difference due to the distribution of $\mathrm{M}^{+}$ between aqueous and organic phases is equivalent to that of $\mathrm{X}^{-}$. The author's group has elucidated that the properties of ionic distribution between aqueous and BLM phases are identical to those between aqueous and organic phases. ${ }^{31,32}$ Curves 1 and 2 in Fig. 6 are the schematic voltammograms at the W1|BLM and the BLM|W2 interfaces. By considering the relation among $E_{\mathrm{W} 1 \mid \mathrm{BLM}}, E_{\mathrm{BLM} \mid \mathrm{W} 2}$ and $E_{\text {W1-W2 }}$ at the same current, the schematic voltammogram for the ion transport across the BLM can be drawn by curve 3. Consequently, the schematic voltammograms for the ion transport coupled with the electron transport is estimated to be curve $4-6$ by curves $5-7$ of Fig. 5 and curve 3 of Fig. 6, and they resembles the observed voltammograms (curves $1-3$ in Fig. 5).

\section{Conclusion}

The electron transport system catalyzed by the membrane-bound enzyme, FDH, was constructed by use of the planar BLM containing TCNQ as an electron-transport mediator. Since TCNQ was reduced to $\mathrm{TCNQ}^{--}$, the proton was mainly uptaken in the BLM to maintain the electroneutrality within the BLM. Therefore, the electron transport across the BLM is always coupled with the proton transport. If the buffer capacity is smaller than the effect of the coexisting cation such as $\mathrm{K}^{+}$, the ion behaves as a counter ion of $\mathrm{TCNQ}^{-}{ }^{-}$in the BLM. When the electromotive force is produced by the electron transport, the ion transport is controlled by the electron transport. The coupling mechanism seems to be available to interpret biofunctions of ion pumps and the energy conversion system. The electromotive force is generated by the electron transport in this case, and it drives the proton transport from $\mathrm{W} 1$ to $\mathrm{W} 2$ across 

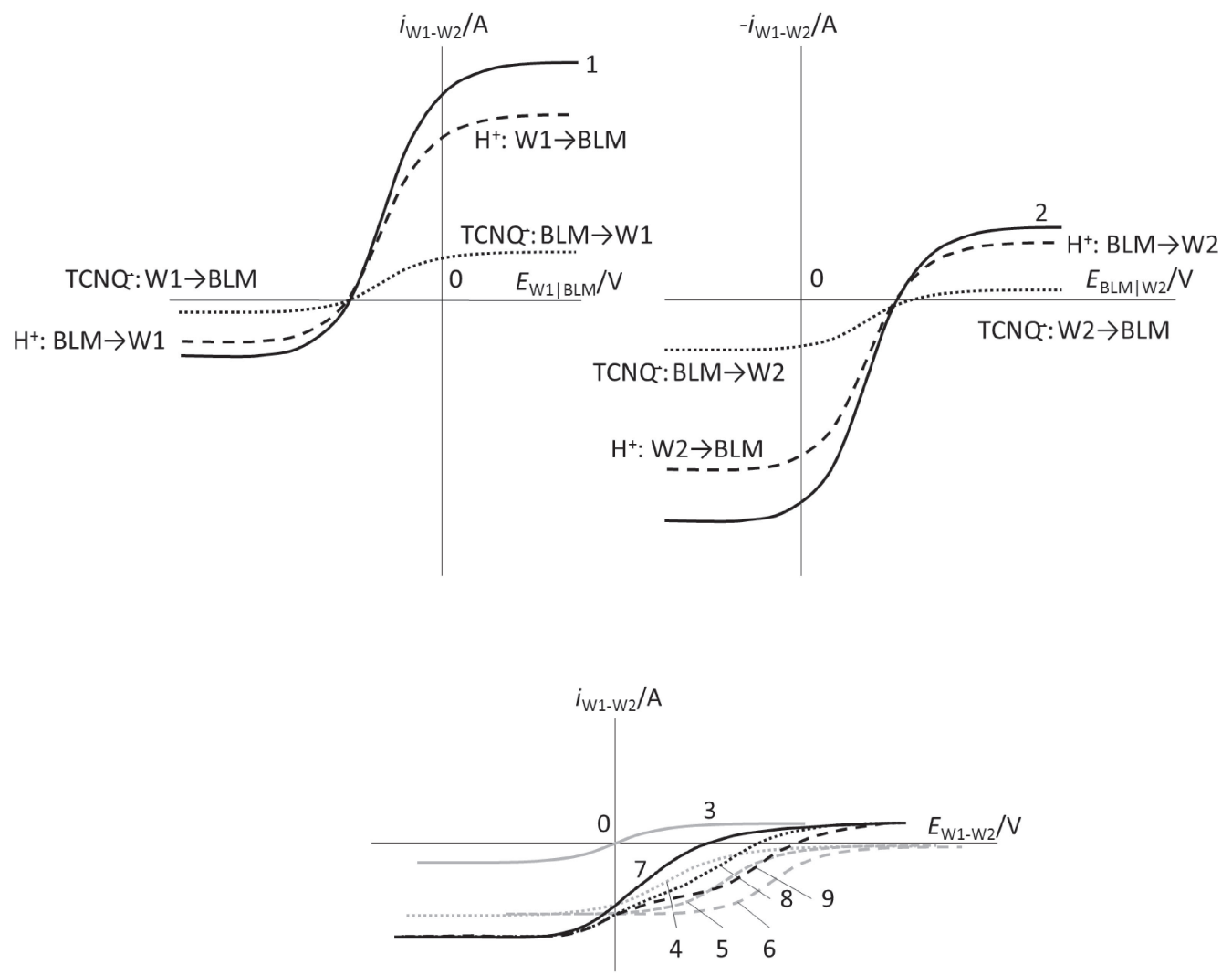

Figure 6. Schematic voltammograms. Curve 1: schematic voltammogram for the ion transport at the W1|BLM interface. Curve 2: schematic voltammogram for the ion transport at the BLM|W2 interface. Curve 3: schematic voltammogram for the ion transport across the BLM. Curves 4-6: schematic voltammogram for the electron transport across the BLM. The ratio of $\mathrm{K}_{3}\left[\mathrm{Fe}(\mathrm{CN})_{6}\right]$ to $\mathrm{K}_{4}\left[\mathrm{Fe}(\mathrm{CN})_{6}\right]$ : 0.1 (curve 4), 1 (curve 5) and 10 (curve 6). Curves 7-9: schematic voltammogram for the total charge transport across the BLM. The ratio of $\mathrm{K}_{3}\left[\mathrm{Fe}(\mathrm{CN})_{6}\right]$ to $\mathrm{K}_{4}\left[\mathrm{Fe}(\mathrm{CN})_{6}\right]: 0.1$ (curve 7), 1 (curve 8) and 10 (curve 9).

the BLM. At the zero current membrane potential, the number of electron transported from $\mathrm{W} 1$ to $\mathrm{W} 2$ is almost equal to that of proton transported from W1 to W2. Since the electric current doesn't flow totally across cell membranes in living cells to hold the electroneutrality, it seems reasonable to assume that the membrane potential across the cell membrane varies to maintain the electroneutrality.

\section{References}

1. P. Mitchell, Nature, 191, 144 (1961)

2. R. Phillips, J. Kondev, and J. Theriot, Physical Biology of the Cell, Garland Science, Taylor \& Francis Group, New York, USA, (2009).

3. J. N. Robinson and D. J. Cole-Hamilton, Chem. Soc. Rev., 20, 49 (1991).

4. P. R. Rich, Biochim. Biophys. Acta, 768, 375 (1984).

5. E. C. Kennett and P. W. Kuchel, IUBMB Life, 55, 375 (2003)

6. L. N. Öjemyr, C. von Ballmoos, R. B. Gennis, S. G. Sligar, and P. Brzezinski, FEB Lett., 586, 640 (2012).

7. E. Sackmann, Science, 271, 43 (1996).

8. L. J. C. Jeuken, S. D. Connell, P. J. F. Henderson, R. B. Gennis, S. D. Evans, and R. J. Bushby, J. Am. Chem. Soc., 128, 1711 (2006).

9. J. F. Rusling, Acc. Chem. Res., 31, 363 (1998).

10. J. G. Koland, M. J. Miller, and R. B. Gennis, Biochemistry, 23, 445 (1984)

11. K. Sun and D. Mauzerrall, Proc. Natl. Acad. Sci. U.S.A., 93, 10758 (1996).

12. K. Sun and D. Mauzerall, Biophys. J., 71, 309 (1996).

13. K. Sasakura, O. Shirai, K. Hichiri, M. Goda-Tsutsumi, S. Tsujimura, and K. Kano, Chem. Lett., 40, 486 (2011)
14. M. Ameyama, E. Shinagawa, K. Matsushita, and O. Adachi, J. Bacteriol., 145, 814 (1981).

15. M. Ameyama and O. Adachi, Methods Enzymol., 89, 154 (1982).

16. Y. Yamada, K. Aida, and T. Uemura, Agr. Biol. Chem., 30, 95 (1966).

17. K. Nakajima, H. Takei, O. Adachi, E. Shinagawa, and M. Ameyama, Clin. Chim. Acta, 151, 307 (1985).

18. K. Matsumoto, O. Hamada, H. Ukeda, and Y. Osajima, Anal. Chem., 58, 2732 (1986).

19. L. R. Melby, R. J. Harder, W. R. Hertler, W. Mahler, R. E. Benson, and W. E. Mochel, J. Am. Chem. Soc., 84, 3374 (1962).

20. G. Wang, X. Fu, J. Deng, X. Huang, and Q. Miao, Chem. Phys. Lett., 579, 105 (2013).

21. K. Hichiri, O. Shirai, Y. Kitazumi, and K. Kano, unpublished data.

22. O. Shirai, Y. Yoshida, and S. Kihara, Anal. Bioanal. Chem., 386, 494 (2006).

23. H. T. Tien, Prog. Surf. Sci., 19, 169 (1985).

24. O. Shirai, S. Ozaki, J. Onishi, N. Kozai, T. Ohnuki, and K. Kano, Chem. Lett., 38, 1038 (2009).

25. T. Akutagawa, G. Saito, M. Kusunoki, and K. Sakaguchi, Bull. Chem. Soc. Jpn., 69, 2487 (1996)

26. S. Ozaki, K. Kano, and O. Shirai, Phys. Chem. Chem. Phys., 10, 4449 (2008).

27. P. H. Barry and J. M. Diamond, J. Membr. Biol., 3, 93 (1970).

28. D. S. Acker and W. R. Hertler, J. Am. Chem. Soc, 84, 3370 (1962).

29. P. A. Rock, J. Phys. Chem., 70, 576 (1966).

30. B. Hille, Ion Channels of Excitable Membranes, $3 r d$ ed., Sinauer Associates, Inc., Sunderland USA, (2001).

31. Y. Yoshida, M. Matsui, O. Shirai, K. Maeda, and S. Kihara, Anal. Chim. Acta, 373, 213 (1998).

32. J. Onishi, O. Shirai, and K. Kano, Electroanalysis, 22, 1229 (2010). 